\title{
Towards a Critical Reappraisal of Kate O'Brien's The Flower of May
}

The Flower of May was published in 1953 while Kate O'Brien (1897-1974) was living in Roundstone, County Galway. This location is important to the context and themes to be discussed as the attractions of family and country - the latter corresponding to the West of Ireland in this novel - are juxtaposed with the growing appeal of Europe and the lure of autonomy. In this, O'Brien's penultimate novel, we are given a conclusion of sorts to the explorations throughout her fiction. It presents the family in the Irish cultural context as restrictive and seems to posit the idea that in order to forge one's way in life, the mother, the family, and Ireland must be left behind. ${ }^{1}$ This does not mean that the family, Ireland, and its mores are rejected outright, rather that while cultural formation is accepted as an intrinsic part of O'Brien's female characters, the past does not necessarily shape the future. In The Flower of May, therefore, O'Brien finally presents an alternative to the acceptance of one's lot - a life with the potential to follow one's own desires. However, as Declan Kiberd writes of O'Brien in Irish Classics, 'in many of her works one has the sense of the country as a place from which a person might start out on an adventure but hardly one in which a transforming experience could happen'. ${ }^{2}$ Subsequently, the decision reached at the end of The Flower of May to locate any 'transforming experience' abroad, that Fanny Morrow might have, is illustrated in O'Brien's last novel, As Music and Splendour, where the events take place in France and Italy, and the heroines live outside of Ireland.

As The Flower of May is not well known, a brief summary of the plot will serve to contextualize the discussion to follow. The setting is 1906 and the novel opens with the marriage of Lilian Morrow to Michael $\mathrm{O}^{\prime}$ Connor. ${ }^{3}$ Lilian's marriage implicitly forces similar expectations on her sister, Fanny, who on her return from school in Brussels, is told by her parents that she will not be resuming her education. Fanny is bitterly disappointed, as is her best friend Lucille de Mellin, who invites Fanny to spend the summer on the continent with her. 
In Europe, Fanny and Lucille are accompanied by Lucille's brothers, Patrice and more occasionally, André, both of whom attempt to woo Fanny. Fanny, however, is not interested in having a relationship with anyone as her travels in Europe reaffirm her desire for a life of her own, an ambition her mother Julia fails to either understand or support. However, Julia's sister, Eleanor Delahunt, gifts Glasalla, the Delahunt ancestral home in County Clare, to Fanny, specifically for this purpose. The novel ends with the death of Julia, which together with her aunt's gift, allows Fanny to realize her dream for an autonomous existence. For Fanny, therefore, her mother's death is a forerunner to a new life.

The Flower of May has not been re-issued since its original publication, and as a result, its contribution to the corpus of O'Brien's work has been overlooked and under-appreciated. On its publication in 1953, O'Brien's friend, the Irish poet and short story writer, John Jordan, briefly summarized the plot and undertook a retrospective exploration of the recurrent themes in all of O'Brien's novels. He also mentioned the novel's 'complexity' and wrote: 'Understandably, critics have been puzzled as to the real theme of the book. Granted that it falls between several not necessarily related stools'. ${ }^{4}$ Jordan's remark points to the difficulty of placing O'Brien's work in a particular theoretical framework, and the varying perspectives put forward by critics of her work reflect this. In Kate O'Brien: A Critical Study, for instance, Adele Dalsimer focused on the friendship, which she read as lesbian, between the heroine, Fanny Morrow, and her Belgian school friend, Lucille de Mellin. ${ }^{5}$ However, Emma Donoghue argues convincingly in "“Out of Order": Kate O'Brien's Lesbian Fiction' that there is little ambiguity about O'Brien's homosexual or lesbian characters in her fiction, and that the close friendship between Fanny and Lucille is not sexual. ${ }^{6}$ More recently, Eibhear Walshe, in his biography, Kate O'Brien: A Writing Life, summarizes the novel in terms of class, its system of female inheritance, and 'the archetypal O'Brien struggle: a young Irish woman who asserts her independence in the face of the constrictions of her family'. ${ }^{7}$ In Kate O'Brien: A Literary Portrait, Lorna Reynolds, while describing the novel as 'a sentimental rehearsal of a theme that has been more strongly rendered before' also observed: ${ }^{8}$

Certain things that are emphasised seem irrelevant, or unexploited ... such as ... the beam of the lighthouse in Glassala [sic] that is never curtained off. There are, however, several new things attempted in The Flower of May. One is the mother-daughter relationship, which is twice portrayed here, that 
of Fanny and her mother and of Lucille and her mother. ... Neither relationship is very convincing, Kate O'Brien's lack of personal experience perhaps showing here. Neither mother is sympathetic to her daughter's real needs. ${ }^{9}$

Here, Reynolds mentions two important issues, the motif of the lighthouse and the relationship between Julia and Fanny Morrow. I argue that the two points are in fact interrelated. Furthermore, I examine Julia's association with the lighthouse, which indicates that she can be read as a symbol for Ireland and thus, as a site at which the cultural norms can be explored. In this novel, therefore, the suggestion of the mother and Ireland as the barrier to personal progress and development is powerfully portrayed. All of the themes mentioned above, as well as $\mathrm{O}^{\prime}$ Brien's continuing argument about the importance of education for women, are present in The Flower of May. For the purposes of this essay, however, my focus will be on the significance of the symbolic representation of the relationship between Fanny and her mother, Julia, as alluded to by the recurring presence of the lighthouse in the text.

As an historical novel set in 1906, the use of temporal distance allows for the confrontation, at a remove, with the cultural implications of both the nineteen-fifties milieu and the Mother Ireland motif. In Inventing Ireland: The Literature of the Modern Nation, Declan Kiberd uses the trope of familial relationships as a symbol for the replacement of the old regime with the new, in the context of the period of the Revival. In his analysis of the father-son relationship in literature, Kiberd argues that the Revival period signified 'a revolt by angry sons against discredited fathers'.$^{10} \mathrm{O}^{\prime}$ Brien employs a similar strategy to Kiberd's discussion of fathers and sons that is particularly explicit in The Flower of May, as the death of the mother, who symbolizes the older generation, facilitates her daughter's freedom. To manipulate Kiberd's analogy further, Fanny Morrow is presented as the new generation, but in contrast to the 'angry sons', there is no 'nostalgic regression into a protected past' but, rather, at the end of the novel, Fanny is posed to 'journey to an open future' ${ }^{11}$ Indeed, Fanny's journey exemplifies the position of single women who left Ireland in their thousands during the nineteen fifties. While women had political and educational equality in the newly-independent Ireland, culturally and legally, opportunities for autonomy had decreased. Rather than rebel, in a cultural context that demanded a strong sense of duty towards parents, young women emigrated. Indeed, Ireland was unusual in that its women tended to emigrate on their own and not as part of a family group. This trend was facilitated by a strong sense of female solidarity in that female relatives financed and supported 
the emigrant. ${ }^{12}$ Similarly, in The Flower of May, it is a female relative that steps in to support Fanny's bid for autonomy.

The theme of emigration in the novel is linked to the lighthouse situated near Julia's ancestral home in County Clare. The lighthouse, which affects a ghostly presence throughout the novel, is highly significant, as its role as symbol of nation is suggested by the reference to it in the text as 'the last glimpse of Erin'. ${ }^{13}$ Additionally, in her travelogue, My Ireland, O'Brien wrote of the lighthouse of Loop Head as 'the exile's last glimpse of Erin .... And it is a fine, severe last glimpse - to stiffen backbones and upper lips of unnerved emigrants, one must hope. ${ }^{14}$ Here, the lighthouse as symbol of Erin fuses, on the one hand, the twin bonds of family and familiarity with, on the other hand, the emigrant's journey into the unknown. Moreover, the setting of the lighthouse at Glasalla in the West of Ireland is significant. In a radio broadcast for Radio Éireann in 1956, O'Brien said: '[T]he West has a certain aristocratic quality in all things ${ }^{\prime}{ }^{15}$ In this regard, $\mathrm{O}^{\prime}$ Brien appears to share the idea, as promoted by Synge, Yeats, and the Cultural Revival movement, of the peasant in the West of Ireland as the true aristocrat. For instance, in Without My Cloak, the peasant girl, Christina Roche, is given 'aristocratic' attributes in order to be deemed worthy of the love of the upper middle-class Denis Considine, who sees in Christina's face, 'an aristocratic fineness which somehow contrived not to contradict but to glorify all her manifest signs of simple stock' ${ }^{16}$ Similarly, Rose Lennane and Clare Halvey in As Music and Splendour are given exceptional attributes, which lift them above the ordinary. Their colleague, Antonio, 'sometimes puzzled with Rose over the differences he found between her and the Sicilian girl, Mariana. ... "Mariana is a dear girl - but she is out-and-out a peasant, in everything. But you- ${ }^{\prime \prime \prime} 17$ In Modernism and the Celtic Revival, Gregory Castle writes that James Joyce, while sharing 'the same sense of being both inside and outside culture' as Yeats and Synge, sought to redefine rather than revive Irish culture in his writing. ${ }^{18}$ Likewise, O'Brien, who shared a similar remove to Joyce from the rural Irish, sought to interrogate the cultural milieu, particularly the middle classes. The revival theme is especially prominent in The Land of Spices. Moreover, in that novel, Anna Murphy has an epiphany that suggests a future as an artist, thereby evoking Stephen Dedalus's experience in Joyce's A Portrait of the Artist as a Young Man. In a similar vein in The Flower of May, it is intimated that Fanny is artistic. In a conversation with Lucille about Glasalla, Aunt Eleanor says: 'So - in so far as I have this recurrent idea that Fanny is a talented creature, I can only assume that she is talented in the literary direction' (p.298). Fanny, as potential artist, therefore, and as an educated woman with a European worldview, is given the attributes to 'redefine' 
her environment. Moreover, it is a place in the West of Ireland that is entrusted to her: '[S]he understood that henceforward all her studies, hopes and dreams would be anchored to her responsibility for Glasalla' (p.229). Thus, the suggestion is that she will imbue the 'aristocratic' peasant people of the West with new vigour.

In the sense of revivalist redefinition, $\mathrm{O}^{\prime}$ Brien also introduces a new class in The Flower of May, the Catholic landed gentry, as Aunt Eleanor, in order to help her niece, needs to be a woman of means. In this way, Eleanor and Glasalla are symbolic, Walshe writes, 'both of an inherent generosity and an aristocratic way of life in Ireland, both of which are lacking in the middle class ${ }^{\prime 19}{ }^{19}$ The $\mathrm{O}^{\prime}$ Connor family, into which Lilian Morrow has married, represent this class: 'The O'Connors ... were vociferously coming up ... and in the Dublin cattle-markets and across the fat acres of Kildare and Meath they made fine fortunes' (pp.18-19). ${ }^{20}$ The unflattering portrayal of this family suggests that the landed gentry serve as an antithesis to the Irish middle classes of the nineteen fifties, who differ from O'Brien's own middle-class milieu. In addition, the bourgeois Morrows of Dublin, inhabitants of the administrative capital of Ireland, are also rejected in favour of the 'real' Irish people of the West, in the Ireland that Fanny inherits. In The Flower of May, the break between the old regime and the new social order, that is a precursor to cultural redefinition, is dramatized in the relationship between Julia and Fanny.

It can be argued that the mother-daughter relationship is not 'convincing', to use Reynolds's word, because it is primarily a symbolic relationship. Indeed, the gradual disintegration of the relationship between Julia and Fanny is framed by the motif of the lighthouse, with its presence during key moments in the plot. Julia and Fanny experience the light in contrasting ways that reflect their diverging paths. Thus, the function of the beam of the lighthouse in the text is to literally throw light on those characters or situations that it illuminates. For Julia, the beam of the lighthouse is a reassuring light, associated with home, as Glasalla 'marked for Julia the boundary, the only one she noticed, of childhood, and so of life' (p.25). Moreover, Julia dies at Glasalla, the place in which she was born, thereby signifying her attachment to home and tradition. This points to Julia's interest in upholding the traditional path for women, as in her worldview, marriage alone should be Fanny's purpose. Fanny, however, does not want to follow in Julia or Lilian's footsteps and when the groom's father remarks that Fanny is 'in the market now', Fanny's response is described as follows: 'Fanny slipped from her father's light hold' (p.20). Fanny, therefore, is definite about what she wants, and 'had no intention either of staying at home idly, or of marrying the first suitable intendent for her hand' (p.66). Her desire 
for autonomy is underlined in the text as she watches the newly married couple set off on their honeymoon: "II'd love to be driving away off in that contraption," said Fanny. "By myself," she added' (p.13). In Fanny's case, therefore, the lighthouse beam symbolizes the movement from the darkness of forcibly suppressed desires by others to the lucidness of self-definition and autonomy. Moreover, her journey towards the light, or European culture, is juxtaposed with Julia's demise into the permanent darkness of death. The significance of darkness and light in the novel has been noted by Aintzane Legarreta Mentxaka in Kate O'Brien and the Fiction of Identity: Sex, Art and Politics in Mary Lavelle and Other Writings, who observes: 'The interplay of shade and light is a device O'Brien was to prioritize in The Flower of May to the extent that the structure of the book relies on it. $^{21}$ In addition, the struggle between darkness and light suggests the conflict between the traditional and the modern, a feature of Irish modernism to which revivalism contributed. As Castle puts it, 'the tension between the archaic and the modern ... characterizes Irish modernism generally'. ${ }^{22}$ This is dramatized by Julia's association with the lighthouse to her past in contrast to Fanny's growing awareness of its role as part of her future.

The lighthouse is utilised by O'Brien to signal her allegiance to modernism and the future, and her representation of Julia can be linked to the portrayal of Mrs Ramsey in Virginia Woolf's novel, To the Lighthouse. Moreover, Woolf's mother was called Julia, and died, like O'Brien's mother, at an early age. ${ }^{23}$ Julia, in The Flower of May, in a similar vein to Mrs Ramsey, devotes herself to familial duty: 'She saw her duties and relationships, and she fulfilled and enjoyed them' (p.24). In addition, the intimate perspective conveyed by Mrs Ramsey's stream of consciousness in To the Lighthouse is mirrored by Julia's long solitary walks in Dublin. There are other parallels between the novels that indicate O'Brien's utilization of modernist characteristics. For instance, Fanny and Julia are removed from their usual habitat of Dublin to the West of Ireland; just as the Ramsey family and Lily Briscoe are positioned in Cornwall. Additionally, in a similar vein to Woolf's novel, The Flower of May is a story that is caught up with the cultural movement of one era to another, with new possibilities, especially for women. Thus, just as Mrs Ramsey represents an unsustainable type of femininity, Julia symbolizes an unsustainable type of culture, as intertextual references to Woolf's work also serve to reinforce the rejection of the ideal of cultural and economic self-sufficiency following on from Ireland's neutrality policy during World War Two, a policy explored by O'Brien in The Last of Summer. While the form of The Flower of May differs greatly from To the Lighthouse, O'Brien's experimentation with multiple genres and layers 
of meaning, as well as the modernist realization of the individual's 'detachment' from others in the portrayal of characters such as Ana de Mendoza in That Lady and Anna Murphy in The Land of Spices, suggests a writer who is, as Mentxaka succinctly points out, 'alert to contemporary experimentation while carrying on a dialogue with tradition'. ${ }^{24}$ The Flower of May and To the Lighthouse, therefore, share a tension between light and darkness, life and death as well as between family ties and autonomy. In addition, the powerful image of the lighthouse in both novels, as well as Woolf's disinclination to specify what it symbolized, paves the way for it to be read in symbolic terms in O'Brien's text.

The portrayal of Julia is conducted in terms of a binary. Her benevolent, kindly character masks the selfish disregard for others in the maintenance of traditional norms. Thus, Julia represents the outwardly perfect, but inwardly flawed Irish Catholic Mother who 'gently' brooks no opposition to her championing of the family on which a patriarchy depends. This is dramatized by Julia's lack of consideration for her sister Eleanor's wishes for the future in the pursuit of her marriage to Joseph Morrow. As a result, Eleanor is compelled to remain in Glasalla, run the estate, and look after their elderly father. In this way, Julia had, Eleanor explains to Lucille de Mellin, 'by sheer gentleness, made my life that which I had no desire to have it be' (p.294). Moreover, Julia continues to focus on preserving the status quo, as her prioritising of Lilian's marriage over Fanny's education implies. This is a theme which O'Brien had explored previously, particularly in her depiction of Hannah Kernahan as a deeply flawed 'Mother Ireland' in The Last of Summer. Elsewhere, I argue that the portrayal of Hannah's outwardly perfect public persona, in contrast to her private capability for stopping at nothing to destroy her son's relationship with his French cousin, is a dramatization of the neutrality policy of World War Two. Hannah's 'deliberate ousting of her niece Angèle from her home' symbolizes an Ireland that 'rejects variance'. ${ }^{25}$ In addition, O'Brien's portrayal of Una Costello in Pray for the Wanderer is a deeply political critique of the representation of the 'ideal' Irish mother as described in the 1937 Irish Constitution, as well as of the cultural ethos needed to sustain that idealization. In a similar vein to Julia Morrow, the depiction of Una Costello's innocence and lack of awareness of the lives of others 'can be read as a criticism of Irish cultural insularity, as well as suggesting that the preservation of ideologies can mask cruelty in their apparent naivety ${ }^{\prime 26}$ Thus, autonomy, in $\mathrm{O}^{\prime}$ Brien's work, is not facilitated by the actions of mothers. Rather, it is enabled by substitute mother figures who recognize a kindred spirit and step in to nurture that spark before it is extinguished. In a similar vein to Mother Helen Archer in The Land 
of Spices, who facilitates the further education of her pupil, Anna Murphy, Aunt Eleanor gives Glasalla to Fanny as 'a means of raising money and independence - the only thing I had which might help her to be free' (p.294). Eleanor explains her decision to Fanny's friend, Lucille: 'You young ones don't see how much some of us desire to promote freedom of action among the intelligent' (p.297). This remark promotes the notion of new ideas, in terms of the growing awareness for change needed in nineteen-fifties Ireland, as the overriding concern with protecting native values and traditions proved inimical to prosperity. ${ }^{27}$

From the opening of the novel, Julia is framed as a character that can be read in symbolic terms. Her attachment to the past is repeatedly illustrated in the text. For instance, she 'often looked abstracted' (p.9), which in art means non-representational or unrealistic. The description of Julia continues:

It was true that, try as she might, her habit of living, her nature, kept her outside what might be reasonably called the immediacies, the actualities of her life ... yet a film she could not brush away, a film which, unwilled by her, her own soul spun - in dreams, in the night, in her walks, unseeing walks, along the streets - floated always between her and all the people (pp.23-4).

The 'film' separating Julia from the people around her is illustrated by her tendency to become so immersed in thoughts of Glasalla that '[s] he forgot that she sat on the green sofa in Mespil Road' (p.26). Indeed, Julia's drawing room in Dublin is described as a room that 'contained her adult life' (p.23), which suggests the idea of a limit, as well as a boundary. Her thoughts return to home and the lighthouse at every opportunity, even while the guests at her daughter's wedding are still present, thereby signalling her attachment to the past: 'The white tower with its finger of light controlled Glasalla, and exacted silence of it, Julia thought. ... And silently now, salvaging her from loneliness, the place, the faithful place, encompassed her' (p.25). As Julia physically retreats to Glasalla whenever she can, and to the shelter and love provided there by her father and sister, this need for retreat in body and mind suggests that in many respects, she has never grown up and furthermore, has not emotionally left her birth family. Additionally, Fanny, while attempting to describe her mother's character to Lucille, says: '[S]he's so restrained that for those who notice it she is, without her knowing it, the most tantalizing kind of film, or photographic place, or something. Oh a very bad one - because you can't make out what anything is that she's - well, 
I suppose, reflecting' (p.157). This remark positions Julia as a 'reflection' of an Irish culture that is lacking in initiative, fixated on the past, and unwilling to adapt or change. Additionally, the portrayal of Julia, as well as her representation as embodiment of Ireland, is reiterated by the description of her illness by Mère Générale in a conversation with Fanny's friend Lucille. Eleanor has written to the Abbess, who tells Lucille: 'Eleanor says that Julia's recent increasing weariness has now become helplessness, and that the doctors say she has an acute anaemia, pernicious, for which they have no answer' (p.166). Anaemia is defined in The Oxford Paperback Dictionary as 'lacking vigour or positive characteristics', which while reminiscent of Julia's characterization, and her representation as Mother Ireland, also suggests O'Brien's perception of the cultural and political stagnation of nineteen-fifties Ireland.

Julia, as symbol of Mother Ireland and a past that is no longer relevant, is juxtaposed with a turning towards a new way of engaging with the world that is dramatized through her relationship with her daughter. Her support for Joseph's decision to bring Fanny's education to an abrupt and premature end changes the family dynamic, as it truncates Fanny's dreams for her future. While Julia's 'abstracted' demeanour suggests an artistic temperament that in other cultural circumstances may have been realized, her sense of duty overrides any attempt to understand that similar trait in her daughter. Fanny's parents, 'had in fact wounded her, and wounds are not forgotten, even by the most loving, even indeed by the most generous' (p.36). Up to this point, Fanny had been happy, 'because [she] loved her roots, her home, her parents and her brothers and sisters, without having to take thought of such natural and easy-going love' (p.40). But that love has a price and Fanny reflects: 'No child, dependent, at bay, and loving its destroyers, could ever, unless absurdly, unless unfairly, speak of private desires to worried-looking parents' (pp.40-1). The idea of parents as 'destroyers' is striking here and with its connotation of reducing something to a useless form, renders Fanny in this instance as stifled. However, Fanny does not disobey her parents as she is a dutiful daughter, which ties in with O'Brien's tendency to avoid active rebellion against parents in her fiction. The incident does, however, mark the beginning of Fanny's realization that mother and daughter are no longer in tune.

While Fanny shares Julia's values in terms of responsibility and duty, their differences are also indicated in the text. For instance, when speaking of Julia, Canon Whelan remarks: 'Fanny is like her. But Fanny will venture further in life' (p.242). The indication is that this 'venture' will encompass the artistic. As Fanny has told Lucille, 
'I mean the impossible. I mean to have no relations whom one loves and to whom one owes the normal considerations of love, and to have instead of them a little secret nest-egg - just enough to go off quietly and get some decent education and sort things out. That's all!' (p.158)

Fanny's wish to 'go off quietly' by herself and 'to have no relations whom one loves' is indicative of the detachment, as mentioned earlier, that is inherent in the portrayal of artistic characters in O'Brien's fiction. In The Land of Spices, for instance, the young Anna Murphy, who appears destined for a future as an artist, is described as 'detached' throughout the novel. Reverend Mother Helen Archer observes that 'for a growing child she gave the impression of detachment which was not very endearing. ${ }^{28}$ In addition, the necessity to go abroad for artistic growth is signalled throughout O'Brien's fiction. For instance, in Pray for the Wanderer, the writer, Matt Costello, although temporarily seduced by the peace and tranquillity of home, finds that there is no room for artistic encouragement or development, and wonders: 'Could he live in de Valera's Ireland, where the artistic conscience is ignored ${ }^{29}$ Ultimately, Matt rejects the legislative and religious narrowness of the new State, and returns to London. Similarly, in The Last of Summer Angèle Maury, as she considers marriage to her cousin Tom, reflects: 'She would cease to be an actress now. ${ }^{\prime 30}$ Thus, Angèle, in order to 'fit' into the Irish cultural environment, is expected to relinquish her artistic identity. In a similar vein to Matt and Angèle, Fanny, in order to grow, must pursue her dream abroad. Indeed, as Kiberd's remark about O'Brien's work at the opening of this essay suggests, Fanny's life experience has yet to occur. Fanny is, therefore, in artistic terms, a work-in-progress and two key descriptions of her in the opening chapter situate her in terms of unfulfilled potential. Cousin Bill, who observes her at Lilian and Michael's wedding reception, opines: 'Fanny is hardly visible ... [T] blue chiffon of her bridesmaid's dress made a wraith of her; she had a mermaid quality' (p.12). The comparison to a ghost and a mythical creature, therefore, suggests that Fanny is as yet unformed.

Fanny's changing perception of the lighthouse is utilized to reflect the trajectory of her journey from child to adult. When she travels to County Clare after Lilian's wedding, Fanny initially experiences the lighthouse beam as harsh and irritating, which reflects her upset and disappointment at the curtailment of her plans for the future. However, as the novel progresses, the light becomes an illuminating force as recurring revelations come about in conjunction with the flash of the lighthouse beam. By the end of the novel, the lighthouse becomes a site of enablement for Fanny's future and as a result, 
a symbol of the future, a life force, a source of creative energy. The visit to Glasalla is organized to assuage Julia's exhaustion after Lilian's wedding. However, Julia is fatally ill and her physical demise is juxtaposed with the gradual build up of occurrences that culminate in Fanny's desire for independence being made achievable. On her arrival at Glasalla, Fanny 'waited for the flash of the lighthouse beam across the wide, empty room' (p.42). Here, Fanny is positioned in a 'wide, empty room' that symbolizes the world that is waiting for her to explore and on which to put her mark. As her dreams have been thwarted by the people who are supposed to nurture her, Fanny is restless and in turmoil. The recurring lighthouse beam fuels her irritation and she wonders how the occupants of Glasalla 'endure' it, 'every minute, night after night?' (p.43) A significant event then occurs. As Fanny looks at the occupants in the room, the beam of light 'took Aunt Eleanor straight on the face - "She's more beautiful than Mother," Fanny thought, with shock' (p.43). When the beam in turn illuminates Julia, 'Fanny caught a weak look on her mother's face, which was turned towards her. In the cold flash she grew up somewhat - because this was the first time she had seen doubt perhaps guilt? - in Julia's disciplined countenance' (p.46). Fanny's reaction to Eleanor's beauty and to the expression caught on her mother's face symbolizes her 'betrayal' of Julia, as she will later reject the mores that have framed Julia's life. In contrast to Julia's 'discipline' which is, as Lucille describes, 'in self-surrender' (p.268), Eleanor's gesture ensures that Fanny's life will be lived differently. This incident marks, in the text, the dividing line for Fanny between childhood and adulthood, a line Julia, with her attachment to Glasalla, has failed to cross. Before Fanny encounters the lighthouse beam again, she will have been exposed to the notion of adventure and autonomy while travelling in Europe with the de Mellin family.

The trajectory of the separation between mother and daughter, tradition and the modern, Ireland and Europe, is finally realized in the chapter where Julia dies. Moreover, the title of this particular chapter, 'The Lighthouse', demonstrates its significance as symbol at this juncture of the novel, as in this chapter, Eleanor's decision to transfer ownership of Glasalla to Fanny is made known and legalized, and the chapter ends with the death of Julia. Indeed, the separation to come anticipates what could be described as the volte-face economic policy of 1958, promulgated by T.K. Whitaker and Sean Lemass in the Programme for Economic Expansion, which had widespread cultural implications. The ideal of self-sufficiency, rejected in favour of the opening of doors to foreign investment and engagement, parallels Julia's 'anaemic' attachment to the past and Fanny's contrasting enthusiasm for Europe. Moreover, the suggestion is that the severance, 
while emotionally difficult, is necessary for growth and progress. Julia's impending death is juxtaposed with Fanny's growing awareness of the implications of Aunt Eleanor's newly revealed decision to leave Glasalla to her. Her turbulent emotions are mirrored by the elements and the lighthouse: 'The stars fought their minute-byminute argument with the whirling lighthouse' (p.226). Fanny is joined outside by Lucille's brother, André, who is utilized in this scene to witness her new-found adulthood. As they converse, André wonders if he hears 'a new vibration in her voice, a ring of strength he had not heard before' (p.228). He asks her: 'Are you challenging the lighthouse, Fanny?' Fanny replies: 'No, André. I'm fraternizing with it' (p.228). Fanny's remark contrasts with her earlier experience of the lighthouse beam as hard and intrusive because in this instance she begins to embrace the lighthouse as being intrinsic to Glasalla and consequently, part of her future. In a significant movement, Fanny turns to 'face the lighthouse' as 'she was moving from unconscious acceptance of Glasalla to clear consideration of it' (p.229). Her changing status is innocently remarked on by André who says: 'You're very grown-up tonight! Very off-hand' (p.231). In Julia's case, the visit to Glasalla coincides with the crossing of the final boundary; from life to death. As Fanny passes the window on the landing while mounting the stairs to visit her mother on her return from Europe, she 'could see the preparatory flickers in the lantern' (p.215). The word 'flickers' indicates Julia's life force, which is in a transitory state. While the beam illuminating her mother's extreme pallor irritates Fanny, her mother refuses to have the curtains drawn, as the recurrent movement is a source of comfort to her: "I sleep to its beat," Julia whispered. "I always did"' (p.216). Finally, the lighthouse is employed to mark the end of Julia's life, as she sleeps eternally 'to its beat' in the nearby family vault: 'Tonight when its inexorable beam passed and repassed over the house that Julia had left, it would also find this other little old house where they must leave her now' (p.283). In addition, Fanny's newly acquired 'grown-up' status is juxtaposed with Julia's death: 'So at noon on the day on which her mother was to die, Fanny became the owner of Glasalla' (p.252). Thus, the old regime is replaced by the new.

As the representative of the new generation, Fanny's life will be the antithesis to that of her mother. Her summer travels have facilitated the consolidation of her desire to make her own way in life, a desire that necessitates the rejection of her mother's principles: family, tradition, and country. As discussed earlier, Fanny does not wish to marry and while both de Mellin brothers declare that they have fallen in love with her, she is not moved by these avowals of affection: 'But my life is mine, and it will be more or less what I make and feel it, 
I hope' (p.102). In a final rejection of a culture that takes Catholicism as a given, Fanny has told the Abbess of her Belgian school that 'she does not believe what the Church requires its children to believe' (p.162). In addition, in her reflections on Glasalla at the opening of the text, Fanny muses:

The smell of Glasalla held childhood. 'Only in a very accurate poem could I recollect the references,' Fanny thought, 'and I shall most likely never learn how to write an accurate poem. That will not matter, naturally. But what will matter is to find out-'. (p.42)

Here, Fanny's use of the verb 'recollect' indicates a distinction between past and present, in contrast to Julia's obsession with the past that prevented her from embracing the 'actualities of her life' (p.23). Additionally, Woolf is evoked once more as Fanny's wrestling with words parallels Lily Briscoe's struggle with problems of artistic form in To the Lighthouse. The distinction between Julia and Fanny is further underlined in a pivotal scene that occurs after Julia's death. Lucille, who had never met Julia, is visibly upset when she views her dead body. She says to Fanny: 'You'd never told me! I - I wasn't prepared! Fanny, Fanny, she's the image of you! ... That is how you will look when you die. Fan! Oh, it was frightening!' (p.268) Fanny reassures her: 'But I won't live as Mother lived, so I won't look like her on my death-bed' (p.268). The exchange emphasizes Fanny's insistence on the differences between herself and her mother, as she is definite about her forthcoming active engagement with the world. Thus, Fanny's future is one that she will negotiate for herself, rather than it being a continuation of the legacy of her mother's generation. Julia, as representative of Ireland and of Irish culture, is literally killed off in order to facilitate the future of the upcoming generation. Thus, cultural norms are rearranged by her mother's death as Fanny chooses an autonomous life that can be seen in her 'revolt' against the tenets that matter to her mother. In this way, the sacrificing of Julia facilitates the potential of her daughter, and the lack of future within the contemporary Irish cultural context is signified by Fanny's plan to go to Europe.

The rejection of Ireland and its mores was not a step taken lightly, as $\mathrm{O}^{\prime}$ Brien had negotiated and explored the bonds of family, religion, and country throughout her fiction. Fanny has secured the time to 'sort things out'. She will eventually return to Glasalla as an educated woman with the potential to advance cultural diversity. Moreover, O'Brien, by facilitating Fanny's artistic potential, gestures to the discovery by Lily Briscoe, in To the Lighthouse, of the brushstroke needed to finish her portrait of Mrs Ramsey. The trajectory of Fanny's 
development from ghostly apparition to 'grown-up and visible' (p.281) is indicated by Cousin Bill's description of her at the end of the text, which parallels his observation of her at the opening of the novel. While surveying the mourners at Julia's funeral, Cousin Bill observes that Fanny is 'misty no longer' but rather her profile is 'clear' and 'white' (p.281). The Flower of May ends as follows: 'Fanny stood on the high-stepped threshold, and observed the lovely night with gratitude to God' (p.335). Fanny's gratitude is more than simply for the beauty of the night. Her father has returned to work, and Fanny can see shades of his old self re-emerging. In addition, Joseph's sister, Edith, will live with him and keep him company, thereby relieving Fanny, his favourite child, of that duty. It is an unusually 'happy ending' for an $\mathrm{O}^{\prime}$ Brien novel in the sense that everything falls neatly into place for Fanny, and she gains her independence without having to make a stand. In Kate O'Brien's fiction, freedom is usually inseparable from loss and separation, and while on the one hand, Fanny has lost her mother, on the other hand, her autonomy can be pursued without cost to anyone living. Fanny, therefore, is free to embark on life in whatever way she chooses. Her standing on the 'threshold' gives concrete evidence of that potential.

\section{NOTES}

I wish to thank Dr Alison Farrell, Dr Michael Farry, Dr Aintzane Legarreta Mentxaka, and Dr Eamon Maher for their helpful comments at various stages of composition. My grateful thanks also to my anonymous reviewers.

1. For reasons of brevity, Ireland will be used throughout to denote the Republic of Ireland on account of the various appellations used from setting to publication of The Flower of May; 1801: United Kingdom of Great Britain and Ireland; 1922: The Irish Free State; 1937: Ireland/Eire; 1949: Republic of Ireland.

2. Declan Kiberd, Irish Classics (London: Granta Books, 2000), p.568.

3. Lilian's story is a manipulation of the genre of romantic fiction in that it begins with the perfect wedding that afterwards unravels in a disastrous fashion. For a discussion on Kate O'Brien and the genre of romantic fiction, see Sharon TigheMooney, 'What Kate Did: Subversive Dissent in Kate O'Brien's The Ante-Room', in Voicing Dissent: New Perspectives in Irish Criticism, ed. by Sandrine Brisset and Noreen Doody (Dublin: Irish Academic Press, 2012), pp.143-158. Available at http:// eprints.nuim.ie/3800/

4. John Jordan, 'Kate O'Brien - A Note on her Themes', The Bell 9.2 (1954), 53-9 (p.53).

5. Adele M. Dalsimer, Kate O'Brien: A Critical Study (Dublin: Gill and Macmillan, 1990), pp.99-111.

6. Donoghue observes that the respective sexual attractions of Agatha Conlon to Mary Lavelle in Mary Lavelle, and Clare Halvey to Luisa Carriaga in As Music and Splendour, are unambiguously rendered, whereas there is no such explicitness in relation to Fanny and Lucille in The Flower of May. See Emma Donoghue, "“Out of Order": Kate O'Brien's Lesbian Fictions' in Ordinary People Dancing: Essays on Kate O'Brien, ed. by Eibhear Walshe (Cork: Cork University Press, 1993), pp.48-9. 
7. Eibhear Walshe, Kate O'Brien: A Writing Life (Dublin: Irish Academic Press, 2006), p.122.

8. Lorna Reynolds, Kate O'Brien: A Literary Portrait (Gerrards Cross: Colin Smythe, 1987), p.86.

9. Reynolds, p.87.

10. Declan Kiberd, Inventing Ireland: The Literature of the Modern Nation (London: Vintage, 1996), p.380. Kiberd's chapter, 'Mothers and Daughters', focuses on female participation in nationalist political struggle rather than analyses of motherdaughter relationships in literature. Kate O'Brien is introduced three pages from the end of the section, in what is an essentially conservative reading of her work, despite the introduction of $\mathrm{O}^{\prime}$ Brien as a banned author. Mother figures are in fact a striking motif throughout O'Brien's fiction with an array of absent mothers, dying mothers, substitute mothers and Reverend Mothers, as well as mothers who symbolize Ireland. Moreover, daughters do revolt, albeit passively rather than actively, in that lives that are mapped out in traditional roles as wives and mothers are rarely assumed.

11. Kiberd, Inventing Ireland, p.389.

12. Women emigrants dominated the outflow of Irish migration during most periods of the nineteenth and twentieth centuries, on account of the shrunken opportunities for home industry, and the post-famine interest in consolidating land holdings, which had an impact on matrimonial opportunities. See R.E. Kennedy, The Irish: Emigration, Marriage and Fertility (London: University of California Press, 1973).

13. Kate O'Brien, The Flower of May (London: Companion Book Club Edition [1953], 1955), p.25. All subsequent references to The Flower of May are in parentheses.

14. Kate O'Brien, My Ireland (London: B. T. Batsford, 1962), pp.34-5.

15. Quoted in Walshe, p.116.

16. Kate O'Brien, Without My Cloak, $3^{\text {rd }}$ edn (London: Virago [1931], 2001), p.287.

17. Kate O'Brien, As Music and Splendour, $2^{\text {nd }}$ edn (Dublin: Penguin [1958], 2005), p.265.

18. Gregory Castle, Modernism and the Celtic Revival (New York: Cambridge University Press, 2001), p.9.

19. Walshe, p.124.

20. The 1903 Wyndham Act, and amending legislation of 1909, made money available for the buying of land which enabled occupiers to become landowners. However, the agricultural labouring class was not included. The result of proprietorship after decades of land agitation facilitated the continuity, in early twentieth-century rural Ireland, of the social patterns and attitudes of the latter half of the nineteenth century. In addition, it is likely that the experience of the famine would have engendered prudence in the managing of assets. Concerns with the preservation of family land became the prevailing interest, as the possession of land equalled status. Moreover, economic consolidation reinforced class structures, which depended on the prospect of inheriting a family-owned business. Emigration and late marriages facilitated the stability of this structure. Thus, in Ireland, the distribution of resources related to land ownership. In addition, the long-awaited realization of owning one's land ensured a rural Ireland wary of change shored up by a government who took pride in perceived self-sufficiency. See Understanding Contemporary Ireland: State, Class and Development in the Republic of Ireland, ed. by Breen et al (Dublin: Gill and Macmillan, 1990).

21. Aintzane Legarreta Mentxaka, Kate O'Brien and the Fiction of Identity: Sex, Art and Politics in Mary Lavelle and Other Writings (Jefferson, North Carolina, and London: McFarland and Company, 2011), p.130.

22. Castle, p.207. 
23. For other intertextual references to Virginia Woolf's work in the novels of Kate O'Brien, see Mentxaka, p.105-6.

24. Mentxaka, p.11.

25. Sharon Tighe-Mooney, 'Exploring the Irish Catholic Mother in Kate O'Brien's Pray for the Wanderer', in Breaking the Mould: Literary Representations of Irish Catholicism. Reimagining Ireland Series, ed. by Eamon Maher and Eugene O'Brien (Bern: Peter Lang, 2011), p.81. Available at http://eprints.nuim.ie/2745/

26. Tighe-Mooney, 'Exploring the Irish Catholic Mother', p.79.

27. At the time of writing, Éamon de Valera's cultural and political programme of self-sufficiency had been established for some time. The 1950s were a gloomy period for the Irish economy. In Social and Economic History of Ireland since 1800, Mary E. Daly writes that during this period, 'real wages stagnated, the population fell and agriculture did not prosper' (p.164). Moreover, she argues: 'The response of the various governments was largely one of paralysis' (p.163). See Mary E. Daly, Social and Economic History of Ireland since 1800 (Dublin: Educational Company of Ireland, 1981).

28. Kate O'Brien, The Land of Spices, $2^{\text {nd }}$ edn (Dublin and London: Millington [1941], 1973), p.226.

29. Kate O'Brien, Pray for the Wanderer, $2^{\text {nd }}$ edn (Harmondsworth: Penguin [1938], 1951), p.98.

30. Kate O'Brien, The Last of Summer (London: The Book Club [1943], 1944), p.128. 